\title{
STRATEGI PEMASARAN DALAM BENTUK PROMOSI TERHADAP MINAT BELI KONSUMEN STUDI DESKRIPTIF : CGV CINEMAS - CENTRAL PARK
}

\author{
Lusia Debora \\ Program Studi Magister Manajemen Universitas Tarumanagara \\ lusia.debora95@gmail.com \\ Eko Harry Susanto \\ Program Studi Magister Manajemen Universitas Tarumanagara
}

\begin{abstract}
A company have a different marketing strategy. The purpose of this research carried out with the title "Marketing Strategy in the Form of Promotion of Consumer Purchasing Interests is to find out the marketing strategy carried out by CGV Cinemas and find out which promotion elements are more in demand by CGV Cinemas consumers located in Central Park Mall. This research was conducted by using descriptive qualitative methods, the technique of collecting primary data was done by means of interviews and secondary data collection techniques through books that were relevant to the object of research, the internet and the annual report of CGV Cinemas. The results of this study indicate that CGV Cinemas consumers know the marketing strategy in the form of CGV Cinemas promotion through advertising media, publications, direct sales, sales promotions and face-to-face sales that encourage consumers to make purchases.
\end{abstract}

Abstrak : Suatu perusahaan pasti mempunyai strategi pemasaran yang berbeda - beda dan beranekaragam. Tujuan penelitian yang dilakukan dengan judul "Strategi Pemasaran Dalam Bentuk Promosi Terhadap Minat Beli Konsumen adalah untuk mengetahui strategi pemasaran yang dilakukan oleh CGV Cinemas serta mengetahui elemen promosi mana yang lebih diminati oleh konsumen CGV Cinemas yang berlokasi di Mall Central Park. Penelitian ini dilakukan dengan menggunakan metode kualitatif bersifat deskriptif, teknik pengumpulan data primer dilakukan dengan cara wawancara dan teknik pengumpulan data sekunder melalui buku - buku yang relevan dengan objek penelitian, internet dan laporan tahunan CGV Cinemas. Hasil penelitian ini menunjukan bahwa konsumen CGV Cinemas mengetahui strategi pemasaran yang berupa promosi CGV Cinemas melalui media iklan, publikasi, penjualan langsung, promosi penjualan dan penjualan tatap muka yang mendorong konsumen untuk melakukan pembelian.

Keywords : Pemasaran, Bauran Pemasaran, Promosi, Minat Beli, Konsumen, Strategi,

\section{Pendahuluan}

Persaingan jumlah bioskop semakin merajalela dan berkembang dengan pesat, berawal dari tahun 2000-an yang dimulai dengan 21 Cineplex yang terdiri dari 21, XXI dan the premier kemudian disusul dengan adanya persaingan dari CGV Cinemas dan Flix Cinema Perusahaan - perusahaan bioskop ini saling berlomba - lomba menghadirkan bioskop yang dinanti - nanti oleh masyarakat, dimulai dari suasana bioskop, letak bioskop, harga tiket pertunjukan film, promosi yang ditawarkan serta kualitas layanan yang diberikan bioskop tersebut kepada konsumennya. Misalnya 21 Cineplex, 21 Cineplex dapat menguasai bioskop - bioskop yang ada di Indonesia khususnya di Jakarta, karena 21 Cineplex ini sudah ada lebih dahulu dengan pesaing - pesaing lainnya dan sudah cukup terbilang lama untuk industry bioskop.

Sama halnya dengan 21 Cineplex, Salah satu bioskop yang saat ini sedang maju dan berkembang adalah CGV Cinemas. Sedikit mengulas sejarah dan cerita dari CGV Cinemas, 
CGV dikelola langsung oleh PT Graha Layar Prima dan rupanya CGV Cinemas telah melakukan beberapa kali pergantian nama atau rebranding. Pada tahun 2006 CGV sebelumnya menggunakan nama Blitzmegaplex, setelah itu mengganti lagi namanya menjadi CGV Blitz, kemudian pada akhir 2016 melakukan pergantian nama kembali menjadi CGV. Mulai 1 Januari 2017, CGV meresmikan nama barunya menjadi CGV Cinemas hingga saat ini (www.cgv.id). Saat ini CGV Cinemas sudah memiliki 48 bioskop yang tersebar diseluruh Indonesia dengan berbagai jenis studio diantaranya seperti Regular, 3D, 4DX, Sphere X, Velvet Class, sweet box dan golden class atau yang lebih dikenal dengan Gold Class.

CGV Cinemas memberikan kemudahan bagi siapa saja untuk melihat promosi yang sedang dilakukan di dalam website resmi CGV www.cgv.id. Promosi yang diberikan pun sangat beragam mulai dari potongan tiket nonton, potongan harga minuman maupun makanan, dan tentu saja dengan syarat dan ketentuan yang berlaku. Tujuan dari pada penelitian ini adalah untuk mengetahui strategi pemasaran dalam bentuk promosi mana yang mempengaruhi minat beli konsumen dengan berbagai macam strategi pemasaran dan promosi yang diadakan oleh CGV Cinemas.

\section{Tujuan Penelitian}

Tujuan dilakukannya penelitian ini adalah:

1. Untuk mengetahui strategi pemasaran CGV Cinemas mana yang paling banyak diminati oleh konsumen

2. Untuk mengetahui elemen promosi CGV Cinemas mana yang digunakan konsumen ketika melakukan pembelian.

\section{Tinjauan Pustaka}

\section{Strategi Pemasaran}

Pemasaran mempunyai suatu arti yang luas, dapat juga dikatakan sebagai suatu kegiatan yang dilakukan oleh suatu organisasi ataupun perusahaan guna untuk mencapai tujuan suatu organisasi ataupun perusahaan. Pemasar bertujuan untuk melayani dan menyediakan kebutuhan masyarakat sehingga kebutuhan masyarakat pun terpenuhi dan terciptanya kepuasaan masyarakat. Berbagai pendapat dikemukakan oleh para ahli mengenai arti dan definisi mengenai pemasaran,

Menurut Kotler dalam bukunya Strategic Management (2001:4) pemasaran merupakan suatu proses social dan aktifitas manusia baik dari management suatu perusahaan maupun kelompok untuk mendapatkan dan memenuhi kebutuhannya serta menciptakan sebuah peluang, pertukaran dan penawaran untuk suatu kelompok atau perorangan guna mencapai terpenuhinya kebutuhan tersebut.

Menurut Stanton dalam buku prinsip pemasaran (2000:28) mengatakan bahwa pemasaran diartikan sebagai suatu sistem dan bagian dari pemasaran baik berupa barang maupun jasa yang didalamnya sudah terdapat perencanaan baik dari segi penentuan harga, target market, pendistribusian barang dan jasa, startegi promosi yang digunakan untuk menarik konsumen dan memenuhi kebutuhan mereka. Menurut Kotler, pengertian strategi pemasaran adalah suatu mindset pemasaran yang akan digunakan untuk mencapai tujuan pemasaran, dimana di dalamnya terdapat strategi rinci mengenai pasar sasaran, penetapan posisi, bauran pemasaran, dan budget untuk pemasaran (Kottler, 2002:54)

\section{Konsep Strategi Pemasaran}

Kotler menjelaskan (2002:56) strategi pemasaran di bagi beberapa konsep, salah satunya Marketing Mix Strategy yang adalah kumpulan dari beberapa variabel yang telah digunakan perusahaan untuk mempengaruhi tanggapan konsumen. Beberapa variabel tersebut diantaranya seperti product, price, place and promotion. Definisi produk menurut Kotler yaitu, sesuatu yang bisa ditawarkan ke pasar untuk mendapatkan perhatian, pembelian, pemakaian, atau 
konsumsi yang dapat memenuhi keinginan atau kebutuhan, sedangkan definisi harga menurut Kotler adalah sejumlah uang yang dibebankan untuk sebuah produk atau jasa. Definisi dari Sumarni dan Soeprihanto (2010:288) tentang saluran distribusi adalah saluran yang digunakan oleh produsen untuk menyalurkan produk tersebut dari produsen sampai ke konsumen atau industri pemakai, dan Promosi (Promotion) adalah suatu bentuk komunikasi pemasaran.

\section{Elemen - Elemen Promosi}

Rangkuti (2009:49) promosi adalah salah satu unsur dalam bauran pemasaran perusahaan yang didayagunakan untuk memberitahukan, membujuk, dan mengingatkan tentang produk perusahaan. Selain mempunyai tujuan dan manfaat, Kotler berpendapat didalam bukunya (2001:98-100) bahwa promosi memiliki empat jenis dalam bentuk kegiatan promosi, antara lain, Periklanan (Advertising) adalah bentuk promosi dari berbagai ide, barang - barang, atau jasa dengan menggunakan bantuan berbagai media yang mempunyai tujuan khusus yaitu merangsang pembeli namun bersifat non - personal. Media yang dipergunakan sebagai alat bantu promosi pun dapat dilakukan dengan berbagai macam sarana seperti surat kabar, majalah, televise, radio, spanduk, banner, billboard dan lain - lainnya. Kini media pun di anggap penting sebagai alat promosi dalam bentuk teknologi komunikasi, Menurut Susanto (2018:50) jaringan komunikasi menawarkan satu jalan untuk saling bergantung, menciptakan ikatan diantara orang - orang yang ada didalamnya melalui teknologi digital, kecepatan komunikasi dalam membangun pemahaman bersama untuk melakukan tindakan kolektif.

Penjualan dengan tatap muka secara langsung atau yang disebut dengan personal selling merupakan bentuk promosi secara personal antar individu dengan melakukan suatu percakapan secara lisan dengan customer yang akan dituju dan mempunyai tujuan untuk merangsang pembelinya. Promosi penjualan atau sales promotion merupakan suatu bentuk promosi yang dilakukan perusahaan untuk menarik dan membujuk konsumen dengan menggunakan berbagai metode dan diawasi langsung oleh perusahaan itu sendiri. Pemasaran langsung atau direct marketing adalah bentuk penjualan perorangan yang bersifat secara langsung dan merupakan penjualan interaktif yang bertujuan untuk menarik konsumen

\section{Minat Beli}

Menurut Kotler dkk (1999:156) minat beli dapat timbul karena adanya proses evaluasi alternatif, seorang individu akan membuat beberapa pilihan mengenai produk atau jasa yang hendak dibeli atau digunakan atas dasar minat.Tetapi Kinnear dan Taylor dalam buku (Thamrin, 2003:142) mengatakan bahwa minat beli merupakan bagian dari perilaku konsumen dalam sikap mengkonsumsi, kecenderungan responden untuk bertindak sebelum keputusan membeli benar - benar dilaksanakan.

\section{Konsumen}

Definisi atau pengertian dari konsumen adalah seorang individu maupun kelompok yang dengan sengaja atau tidak sengaja memperoleh atau membeli barang atau jasa untuk dikonsumsi secara pribadi ataupun dengan bersama - sama, Kotler "Principles of Marketing" (2000:18).

\section{Metode Penelitian}

Dalam mencapai tujuan penelitian, metode penelitian yang akan digunakan pada penelitian ini adalah ini adalah metode penelitian kualitatif. Lokasi penelitian akan dilakukan di CGV Cinemas Central Park. Subjek penelitian yang akan di ambil oleh peneliti adalah seorang yang berusia 20 sampai dengan usia 40 tahun karena pada usia tersebut menurut Santrock, (1999:33) dianggap tergolong dewasa muda yang disertai dengan masa transisi baik transisi secara fisik (physically trantition) maupun transisi peranan social. Ditambahkan dalam 
buku Minks, Knoers \& Haditono (2001:24) pada umur dewasa muda merupakan puncak dari perkembangan social masa dewasa, dimana pada masa social dewasa ini seseorang sudah dapat merasakan empati.

Periode penelitian tesis ini akan dilakukan pada bulan September 2018 hingga April 2019, untuk laporan penelitian dalam bentuk penulisan tesis akan dilaksanakan pada bulan Januari 2019 dan harapan peneliti untuk dapat menyelesaikan laporan penelitian ini pada bulan Mei 2019.

\section{Hasil Analisis Data}

1. Strategi Pemasaran CGV Cinemas - Central Park

Berdasarkan analisis temuan penelitian, ditemukan bahwa strategi pemasaran yang lebih banyak diketahui oleh konsumen CGV Cinemas adalah strategi pemasaran marketing mix atau bauran pemasaran yang terdiri dari 4P (Product, place, price and promotion) dalam bentuk promosi, hal ini berdasarkan hasil wawancara peneliti dengan beberapa konsumen CGV Cinemas. Sejalan dengan itu, salah satu konsumen, sebagai informan pertama menyatakan mengetahaui strategi pemasaran CGV Cinemas melalui promosi yang ada melalui berbagai macam media social. Hal senadapun diperkuat oleh informan kedua, yang berpendapat bahwa mengetahui strategi pemasaran melalui promosi yang dapat dibeli melalui traveloka. Dari hasil penelitian ditemukan pula bahwa responden berpendapat bahwa lokasi CGV Cinemas cukup dikatakan strategis dan tepat karena terletak di sebuah mall yang cukup besar yang menyediakan berbagai keperluan dan kebutuhan konsumen secara lengkap. Price (harga) dilihat dari harga pelanggan cukup puas dengan harga yang sebanding dengan fasilitas yang diberikan CGV Cinemas dan promosi yang dianggap cukup beraneka ragam dengan cara melalui periklanan (advertising), penjualan tatap muka (personal selling), publikasi (publicity), penjualan promosi (sales promotion) dan penjualan langsung (direct selling)

2. Elemen - Elemen Promosi yang dilakukan CGV Cinemas

Berdasarkan hasil wawancara dan analisis dengan para konsumen CGV Cinemas ditemukan bahwa promosi yang diketahui oleh seorang konsumen CGV melalui periklanan, hal ini disampaikan oleh informan lainnya yang berpendapat bahwa promosi yang ia ketahui berasal dari periklanan di social media maupun group chatting WhatsApp, iklan digital maupun pihak ketiga yang bekerjasama dengan CGV. Diperkuat dengan seorang informan kunci yang merupakan seorang VIP (very important person) member CGV Cinemas ikut berkomentar dan memberikan pendapatnya mengenai pentingnya promosi bagi suatu perusahaan dan asal muasal informasi promosi yang ia dapatkan. Informan ini merasakan bahwa promosi itu merupakan bagian penting dalam kegiatan strategi pemasaran karena dianggap sangat berguna untuk menarik konsumen dan ia pun mendapatkan informasi promosi dari berbagai macam cara, ia juga tidak pernah merasakan kebingungan terhadap promosi mana yang akan digunakan, bagi Agung tanpa adanya promosi dari pihak ketiga, terlebih lagi ia sudah merasakan promo melalui fasilitas VIP Membership,

Pada elemen penjualan tatap muka (Personal Selling), peneliti menemukan bahwa promosi yang dilakukan CGV Cinemas ini, konsumen mengetahui promosi yang ada melalui karyawan CGV Cinemas dengan cara menghampiri konsumennya untuk menginformasikan mengenai promosi melalui CGV Cinemas membership. Dengan adanya publisitas (Publicity) konsumen mengetahui promosi melalui program CSR (Corporate Social Responsibility) dengan memberikan kesempatan kepada para penyandang disabilitas khususnya kepada anak - anak yang kurang dalam penglihatan. Salah seorang konsumen CGV Cinemas mengetahui dan memaknai lebih jauh promosi 
CGV Cinemas melalui program Corporate Social Responsibility yang bertemakan "Bioskop Tanpa Batas". Hal ini disampaikan oleh informan ke tiga

Selain melakukan program Corporate Social Responsibility, CGV Cinemas pun turut andil dalam rangka mendukung pesta olah raga Asia, Asean Para Games sebagai sponsorship yg dilaksanakan pada tahun 2018 silam. Melalui promosi penjualan (Sales Promotion) konsumen CGV Cinemas mengetahui promosi yang ada melalui karyawan CGV Cinemas yang mempunyai posisi sebagai kasir pada saat konsumen ingin melakukan pembelian tiket dan membayar tiket tersebut kepada seorang kasir. Informan lainnya berpedapat sebagai berikut,

Selain itu salah satu konsumen CGV Cinemas mengatakan bahwa promosi yang beliau ketahui berasal dari seorang temannya yang bekerja sebagai ticketing di CGV Grand Indonesia dengan kata lain konsumen ini mendapatkan informasi secara langsung dari seorang temannya yang merupakan karyawan dari CGV Cinemas melalui penjualan langsung (direct selling)

\section{Kesimpulan dan Saran \\ Strategi Pemasaran CGV Cinemas - Central Park}

Berdasarkan hasil wawancara dengan beberapa konsumen CGV Cinemas - Central Park ditemukan bahwa CGV Cinemas - Central Park memiliki jenis studio yang beranekaragam, lokasi CGV Cinemas yang berada diMall Central Park, dari hasil penelitian disimpulkan bahwa responden berpendapat bahwa lokasi CGV Cinemas cukup dikatakan strategis dan tepat karena terletak di sebuah mall yang cukup besar yang menyediakan berbagai keperluan dan kebutuhan konsumen secara lengkap. Dilihat dari harga pelanggan cukup puas dengan harga yang sebanding dengan fasilitas yang diberikan CGV Cinemas dan promosi yang dianggap cukup beraneka ragam dengan cara melalui periklanan (advertising), penjualan tatap muka (personal selling), publikasi (publicity), penjualan promosi (sales promotion) dan penjualan langsung (direct selling)

\section{Elemen - Elemen Promosi yang dilakukan CGV Cinemas}

Berdasarkan hasil wawancara dengan para konsumen, peneliti menemukan bahwa promosi yang dilakukan CGV Cinemas ini, memiliki kecenderungan bahwa mayoritas pengunjung CGV Cinemas mengetahui promosi yang ada melalui periklanan baik melalui media sosial, situs resmi CGV Cinemas, dan promosi melalui pihak ketiga yang bekerjasama dengan CGV Cinemas.

Berdasarkan hasil dari penelitian ini, maka ada beberapa saran yang dapat diberikan oleh peneliti, yaitu sebagai berikut:

1. Saran Akademis dalam Strategi Pemasaran dan Promosi CGV Cinemas - Central Park

Berdasarkan hasil temuan penelitian yang dilakukan pada saat di lapangan maupun saat dilakukannya analisis, peneliti berharap dan menyarankan penelitian dapat diperluas dengan menggunakan dua metode, yaitu metode kuantitatif dan kualitatif dengan meneliti dengan menggunakan sampel dan wawancara mendalam antara lain dengan cara seperti :

a. Membuat penelitian kualitatif dengan meganalisis perilaku konsumen seperti yang dikemukakan oleh Sopiah dan Sangadji (2013)

b. Dilanjutkan dengan membuat penelitian kuantitatif dengan kuantitatif dengan menggunakan sampel, antara lain dilihat dari Pengaruh Direct Selling terhadap Purchase Decision seperti yang dikemukkan oleh Durianto (2003)

2. Saran Praktis dalam Strategi Pemasaran dan Promosi CGV Cinemas Central Park

Saran praktis yang diberikan adalah adanya harapan melalui penelitian ini, diharapkan CGV Cinemas dapat memperluas pemasaran bukan hanya melalui marketing 
mix saja tetapi dengan menggunakan elemen - elemen strategi pemasaran lainnya. Dengan adanya respon positif yang diberikan oleh konsumen CGV Cinemas - Central Park diharapkan CGV Cinemas dapat melalukan promosi lebih banyak lagi melalui personal selling, direct selling, dan publikasi.

\section{Daftar Pustaka}

Armstrong, Gary \& Kotler, Philip. 1999. Prinsip- Prinsip Pemasaran. Jakarta: ErlanggaSindoro dan Benyamin Molan. Jakarta: Penerbit Prenhalindo.

Durianto. 2003. Strategi Memimpin Pasar. Jakarta. PT Gramedia puataka utama

Kunaryo dan Sutanto. 2004. Strategi Belajar Mengajar, Bandung: Remaja Rosdakarya

Kotler, Philip and Keller, Kevin Lane. 2001. Manajemen Pemasaran. Terjemahan oleh : Bob Sabran, Edisi ke Tiga belas Jilid 2. Jakarta : Erlangga

Kotler, Philip. 2002, Manajemen Pemasaran, Edisi Millenium, Jilid 2, Jakarta : PT Prenhallindo

Monks, A.M.P. Knoers, Siti Rahayu Haditono. 2001. Psikologi Perkembangan. Jakarta : Raja Grafindo Persada

Rangkuti, Freddy. 2009. Strategi Promosi yang Kreatif dan Analisis Kasus Integrated Marketing Communication. Jakarta : PT. Gramedia Pustaka Utama

Santorck, John W. 1999. Educational Psychology, $5^{\text {Th }}$ Edition.

Sangadji, E. M., \& Sopiah. 2013. Consumer Behavior: Perilaku Konsumen dan Strategi Pemasaran Jilid 2. Jakarta: Erlangga.

Stanton, William J. 2000. Prinsip Pemasaran. Jakarta. Erlangga.

Sumarni, Murti dan John Soeprihanto. 2010. Pengantar Bisnis (Dasar-dasar Ekonomi Perusahaan). Edisi ke 5. Yogyakarta: Liberty Yogyakarta

Susanto, Eko Harry. 2018. Komunikasi Manusia Teori dan Praktek Dalam Penyampaian Gagasan Jakarta: Mitra Wacana Media

Thamrin, Abdullah. 2003. Manajemen Pemasaran. Jakarta : Raja Grafindo 